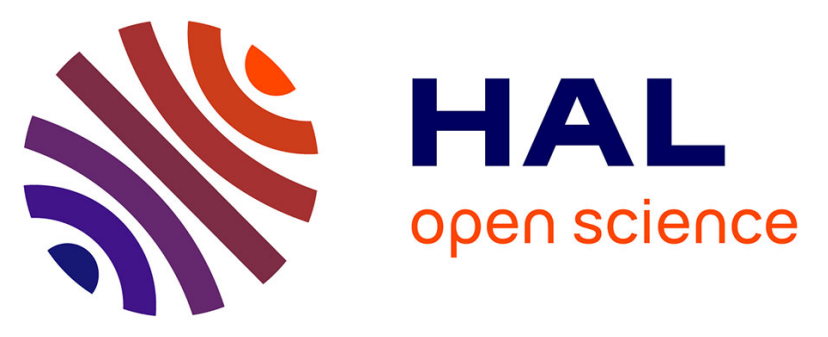

\title{
Phragmites australis meets Suaeda salsa on the "red beach": Effects of an ecosystem engineer on salt-marsh litter decomposition
}

Lijuan Cui, Xu Pan, Wei Li, Xiaodong Zhang, Guofang Liu, Yao-Bin Song, Fei-Hai Yu, Andreas Prinzing, Johannes H C Cornelissen

\section{To cite this version:}

Lijuan Cui, Xu Pan, Wei Li, Xiaodong Zhang, Guofang Liu, et al.. Phragmites australis meets Suaeda salsa on the "red beach": Effects of an ecosystem engineer on salt-marsh litter decomposition. Science of the Total Environment, 2019, 693, pp.133477. 10.1016/j.scitotenv.2019.07.283 . hal-02280459

HAL Id: hal-02280459

https://hal-univ-rennes1.archives-ouvertes.fr/hal-02280459

Submitted on 18 Nov 2019

HAL is a multi-disciplinary open access archive for the deposit and dissemination of scientific research documents, whether they are published or not. The documents may come from teaching and research institutions in France or abroad, or from public or private research centers.
L'archive ouverte pluridisciplinaire HAL, est destinée au dépôt et à la diffusion de documents scientifiques de niveau recherche, publiés ou non, émanant des établissements d'enseignement et de recherche français ou étrangers, des laboratoires publics ou privés. 
Phragmites australis meets Suaeda salsa on the "red beach": effects of an ecosystem engineer on salt-marsh litter decomposition

Lijuan Cui ${ }^{\text {a }}$, Xu Pan ${ }^{\text {a, * }}$, Wei Li ${ }^{\text {a }}$, Xiaodong Zhang ${ }^{\text {a }}$, Guofang Liu ${ }^{\text {b }}$, Yao-Bin Song ${ }^{\text {c }}$, FeiHai Yu ${ }^{d}$, Andreas Prinzing ${ }^{e}$, Johannes H.C. Cornelissen ${ }^{f}$

${ }^{a}$ Beijing Key Laboratory of Wetland Services and Restoration, Institute of Wetland

Research, Chinese Academy of Forestry, Beijing, 100091, China

b State Key Laboratory of Vegetation and Environmental Change, Institute of Botany,

Chinese Academy of Sciences, Beijing, 100093, China

${ }^{\mathrm{c}}$ Key Laboratory of Hangzhou City for Ecosystem Protection and Restoration, College of Life and Environmental Sciences, Hangzhou Normal University, Hangzhou, 310036, China

${ }^{\mathrm{d}}$ Institute of Wetland Ecology \& Clone Ecology, Taizhou University, Taizhou, 318000,

China

e Université de Rennes 1, Centre National de la Recherche Scientifique Campus de Beaulieu, Research Unit Ecobio, Bâtiment 14 A, 35042 Rennes, France

${ }^{\mathrm{f}}$ Systems Ecology, Department of Ecological Science, Faculty of Earth and Life

Sciences, Vrijeee Universiteit University Amsterdam, 1081 HV Amsterdam, The Netherlands 
${ }^{*}$ Correspondence author. Present address: No. 1 Dongxiaofu, Xiangshan Road, Haidian District, Institute of Wetland Research, Chinese Academy of Forestry, Beijing 100091, China.Email: xu_pan_decom@126.com

\section{ABSTRACT}

Suaeda salsa is a pioneer species in coastal wetlands of East Asia and recently an ecosystem engineer species, Phragmites australis, has started to enter into S. salsa communities owing to either autogenic or external drivers. The consequences of this phenomenon on the ecosystem functions of coastal wetlands are still unclear, especially for decomposition processes. Here we compared the decomposition rate of $S$. salsa litter, and associated litter chemistry dynamics, between sites with and without $P$. australis encroachment. We conducted a litter transplantation experiment to tease apart the effects of litter quality and decomposing environment or decomposer community composition. Our results showed that $P$. australis encroachment led to higher carbon and phosphorus losses of $S$. salsa litter, but equal losses of total mass, lignin, hemicellulose and nitrogen. Phragmites australis encroachment might affect decomposition rate indirectly by making S. salsa produce litter with higher lignin concentrations or via increasing the fungal diversity for decomposition. Moreover, $P$. australis as an ecosystem engineer might also alter the allocation of total phosphorus between the plants and the soils in coastal 
wetlands. Our findings indicate that $P$. australis could impact aboveground and belowground carbon and nutrient dynamics in coastal wetlands, and highlight the important consequences that encroaching plant species, especially ecosystem engineers, can have on ecosystem functions and services of coastal wetlands, not only in East Asia but probably also elsewhere in the world.

Keywords: aboveground and belowground processes, carbon and nutrient cycling, ecosystem engineer, litter decomposition, plant encroachment, salt marsh 


\section{Highlights}

-Phragmites australis encroachment affected the soil properties of salt marshes.

- Phragmites australis encroachment affected the litter qualities of Suaeda salsa.

-Decomposition of S. salsa litter was affected by P. australis encroachment.

- Salt-marsh ecosystem functions and services could be altered by such an encroachment. 
1. Introduction

Encroachments of new species into ecosystems, which lead to dramatic changes in vegetation composition, might have significant consequences for ecosystem functions (Hibbard et al., 2001; Archer et al., 2017; Nolte et al., 2019). In particular, new species encroachments might affect the quality and quantity of primary and secondary production, decomposition and nutrient cycling, and the pools and flows of materials (Eldridge et al., 2011; Friedrich et al., 2011; Zhou et al., 2018). They might also affect the nutrient resources within biogeochemical cycles, or affect the trophic resources within food webs and on physical resource such as living space, sediment, light, or water (Vitousek, 1990; Kelleway et al., 2017). Moreover, such consequences might be particularly large if the encroached species are ecosystem engineers, i.e. they direct or indirectly modulate resources availability of ecosystems (Guy-Haim et al., 2018), e.g. nitrogen fixation by Myrica faya changing the nutrient status of entire islands on Hawaii (Vitousek, 1990). The consequences of new species encroachments have been widely described in many kinds of terrestrial ecosystems (Schlesinger et al., 1990; McLaren et al., 2017; Zhou et al., 2018), mainly focusing on woody plant species (Hibbard et al., 2001), but the consequences of non-woody-plant species encroachments have seldom been tested especially in coastal wetlands (but see Nolte et al., 2019).

Coastal wetlands, e.g. salt marshes, are dynamic systems with sedimentation and erosion 
causing progressive and retrogressive succession respectively. Succession-driven changes in salt marshes can lead to dramatic changes in biodiversity (Powell et al., 2011), nutrient cycling (Windham and Ehrenfeld, 2003), microorganisms (Otto et al., 1999; Ravit et al., 2003) and food webs (Belnap et al., 2005). These dynamics can be natural, e.g. as a consequence of changing spatial water and sediment flow patterns in the sea, or can be driven by external factors, e.g. fresh water inflow from higher areas, fertilization, climatic changes or human alteration of sedimentation patterns (Berendse et al., 2001; Gedan and Bertness, 2009). In temperate salt marshes worldwide, common reed, Phragmites australis (Cav.) Trin. Ex Steud., is often the species that defines the succession from vegetation dominated by halophytes to reed beds, in response to sedimentation or desalinization and/or by actively promoting these processes. The expansion of $P$. australis might be due to natural succession or due to environmental change such as increasing elevation and decreasing salinity (Minchinton, 2003). Indeed, P. australis is a true ecosystem engineer, which can enhance the sedimentation in coastal areas (Rooth and Stevenson, 2000; Hughes et al., 2016) and decrease the phosphorus availability below its stands due to high rates of phosphorus uptake (Templer et al., 1998); and it can also have either positive (Windham and Ehrenfeld, 2003) or neutral (Otto et al., 1999) effects on soil microbial activities and $\mathrm{N}$ mineralization rates (Ehrenfeld et al., 1997). The consequences of $P$. australis as invasive species have been documented before (Bernal et al., 2015), but as a native species in East Asia, there is a lack of empirical evidence about 
the consequences of $P$. australis encroachments on ecosystem functions and services, especially for decomposition processes.

Halophytic pioneers of salt-marshes not only are key-stone species initiating salt marsh succession, they also provide other paramount ecosystem services (sensu Díaz et al., 2007), as food crops, e.g. Salicornia spp. worldwide and edible oils the seed of Suaeda salsa (L.) Pallas (Zhao et al., 2002) or for their recreational or cultural values. In East Asia, several species have enormous recreational, cultural and economic values because of their spectacular red autumn display, for instance $S$. salsa on the east coast of China and the Japanese coast; $S$. salsa dominates stands in the salt marshes of coastal intertidal areas that turn bright red in autumn (Wu et al., 2011). The management of these areas to retain large Suaeda communities against the encroachments and ecosystem alteration and consequently degradation of ecosystem services (especially cultural service or ecotourism) by $P$. australis has been a real challenge (Song et al., 2011). This is mainly because the drivers of their succession are poorly understood. In particular, the role of $P$. australis therein as an ecosystem engineer in decomposition processes is still unclear. Decomposition is a fundamental process in salt marshes (McLusky and Elliott, 2004), facilitating the cycling of nutrients and other chemical elements, and supporting primary production and important food webs (Graça, 2001; Quintino et al., 2009). Other studies mostly focused on decomposition of $P$. australis itself (but see Warren et al., 2001; 
Windham and Ehrenfeld, 2003). However, as an ecosystem engineer, can it also alter the decomposition of other species in the community? If so, this could give the potential for important feedbacks to ecosystem functioning and perhaps accelerated succession.

To answer this question, we conducted a litter transplantation experiment using the litter bag method to compare the decomposition rate of $S$. salsa litter, i.e. the losses of total mass, and of biochemical compounds (lignin and hemicellulose) and elements (carbon, nitrogen and phosphorus) known to be important determinants of decomposition, between sites with and without $P$. australis encroachment. This design allows us to tease apart the aboveground and belowground drivers of litter decomposition rates between sites. We collected (whole-plant) litter of $S$. salsa from two types of sites and incubated reciprocally in both: one is the monospecific $S$. salsa community (Site $S$ ) and the other is the $S$. salsa community with the coexistence of $P$. australis (Site SP). We addressed the following three specific questions: (1) Is there a significant difference in litter decomposition rates between monospecific $S$. salsa stands and mixed $S$. salsa $-P$. australis stands? (2) If so, does this difference depend on where the litter comes from via litter quality or on where the litter is incubated via the decomposing environment including the decomposer community? (3) If the latter, does the decomposer community effect depend on functional diversity in terms of different groups of invertebrate and microbial decomposers (Wardle et al., 2004)? We used two kinds of mesh sizes to test the 
effect of different groups of invertebrates on the litter decomposition of $S$. salsa litter and also quantified the soil bacteria and fungal communities in both sites. This study will enhance fundamental knowledge about salt marsh succession and feedbacks and ecosystem engineering effects in general and provide useful insight for managing important ecosystem functions of coastal wetlands.

\section{Materials and Methods}

\subsection{Study sites}

The study site was located in the Liaohe Estuary National Nature Reserve (40 $45^{\prime}-$

$\left.41^{\circ} 08^{\prime} \mathrm{N}, 121^{\circ} 28^{\prime}-122^{\circ} 00^{\prime} \mathrm{E}\right)$ in Liaoning Province, Northeast China. This area belongs to a semi-humid temperate monsoon climate with a mean annual temperature of $8.4{ }^{\circ} \mathrm{C}$ and a mean annual precipitation of $623.2 \mathrm{~mm}$ (ranging from $326.6 \mathrm{~mm}$ to $916.4 \mathrm{~mm}$ ). The

frost-free period is about 175 days per year. The tide in this area is irregular semi-diurnal and soils of this area are classified as coastal solonchaks (FAO, 2006). The vegetation is mostly herbaceous and the prevailing vegetation types are virtually monospecific stands of the annual forb $S$. salsa and of the perennial grass $P$. australis, respectively, and their mixtures due to $P$. australis encroachment. In order to test the influence of $P$. australis encroachment into the $S$. salsa community, we selected two sites: one hosting $S$. salsa stands (site S) and the other hosting $S$. salsa coexisting with $P$. australis (site SP). Both sites had similar elevations and tidal regime with a distance of $18 \mathrm{~km}$ between them. 


\subsection{Experimental design}

We carried out a litter transplantation experiment between the two types of sites mentioned above using the litter bag method. For each type of site, fresh (whole-plant) litter of $S$. salsa was collected directly after senescence in early November, 2014 and airdried in shade for 2 weeks before litter incubation. In order to test the effects of different soil invertebrates on litter decomposition, we used litter bags with different mesh sizes:

coarse mesh with $1 \mathrm{~mm}$ holes and fine mesh with $0.5 \mathrm{~mm}$ holes. Note that the difference between two mesh sizes was small because the leaf litter of $S$. salsa was really small when air-dried, ruling out larger mesh sizes because of the risk of litter fragments falling out. For the air-dry litter, we carefully cleaned the bulk soil on the litter by hand before putting the sample into the litter bag. We put about $20 \mathrm{~g}$ air-dried litter in each litter bag. Besides, another five litter subsamples were also weighed and oven-dried $\left(80^{\circ} \mathrm{C}\right.$ for 48 h) to estimate the initial water content, i.e. (air dry weight-oven dry weight)/air dry weight and in turn estimate the oven-dry weight of litter samples in the litter bags. These samples were subsequently measured for initial chemical content (see below). The litter bags were incubated in the field by vertically inserting each litter bag into the soil. The average depth from top to bottom was $30 \mathrm{~cm}$, in order to keep the litter incubated at a similar soil depth and avoid exposure of the litter to the air. The distance between litter bags was around $20 \mathrm{~cm}$. We incubated the plant litter reciprocally: from site $\mathrm{S}$ in both site 
$\mathrm{S}$ and site SP, and from site SP in both sites (Fig. 1). The whole experiment lasted for 9 months starting at the end of November 2014, with two harvests (one after 5 months right after the frozen season, and the other after 9 months before the start of the litter

production in the following year). We had 5 replicates for each treatment per harvest and there were 80 litter bags in total. After litterbag retrieval, we cleaned and subsequently oven-dried each sample $\left(80{ }^{\circ} \mathrm{C}\right.$ for $\left.48 \mathrm{~h}\right)$ and calculated $\%$ mass loss.

\subsection{Measurements of the remaining litter}

The remaining litter was oven dried at $80{ }^{\circ} \mathrm{C}$ overnight with subsequent grinding using a modified ball mill. An appropriate amount of material was then weighed in tin capsules prior to analysis. The samples were analyzed, along with analytical quality controls on an elemental analyzer (N1500, Carlo Erba, Milan, Italy) for the measurements of total carbon and total nitrogen concentrations, and the total phosphorus concentration was measured by inductively coupled plasma emission spectroscopy (Perkin Elmer Optima 3000 ICP Spectrometer, Waltham, MA). Moreover, the concentrations of lignin and hemicelluloses were measured by the extraction of non-ligneous compounds as described in (Freschet et al., 2010). The changes of lignin, hemicellulose, total carbon, total nitrogen and total phosphorus were then calculated as the post-exposure concentration divided by the pre-exposure concentration (fraction of the initial concentration). The loss percentages were calculated as the changes calibrated by the litter mass losses (Pan et al., 
2015).

\subsection{Soil property measurements}

At each site, we randomly selected three soil samples, which we separated into different soil layers: 0-10 cm, 10-20 $\mathrm{cm}$ and 20-30 $\mathrm{cm}$ depth. Soil samples were brought into the laboratory, air dried and passed through a $1 \mathrm{~mm}$-sieve before measurement. A five-gram subsample of each soil sample was shaken with $25 \mathrm{~mL}$ demineralized water in an Eppendorf tube for $30 \mathrm{~min}$ at $250 \mathrm{rpm}$ and the solution was used to measure soil electrical conductivity (soil EC, $\mu \mathrm{s} \mathrm{cm}^{-1}$ ): the solution was centrifuged at $5000 \mathrm{rpm}$ for $5 \mathrm{~min}$, and the supernatant solution was measured for EC. In addition, we measured soil organic carbon (SOM, $\mathrm{mg} \mathrm{g}^{-1}$ ) by subtracting soil inorganic content from soil total carbon, which was measured by TOC analyzer (SSM 5000A; Schimadzu, Japan). All air-dry soil samples were oven-dried at $105{ }^{\circ} \mathrm{C}$ for six hours and measured for water content, and soil nutrient contents of samples were expressed per unit oven-dry mass. In addition, the soil total carbon $(\mathrm{C})$ and total nitrogen $(\mathrm{N})$ concentrations were analyzed on an automated elemental analyzer the same as the measurement of litter. The other soil properties, such as soil total phosphorus $(\mathrm{P})$ and soil base cations $(\mathrm{K}+\mathrm{Ca}+\mathrm{Mg})$, were analyzed by inductively coupled plasma emission spectroscopy (Perkin Elmer Optima 3000 ICP Spectrometer, Waltham, MA). For each soil variable in each site, we averaged the values of different soil layers as the mean soil property. 


\subsection{Measurements of soil bacteria and fungi diversity}

We also collected three soil samples in each type of site for measurements of bacterial and fungal communities in late September, and each soil sample was the mixture of three sub-samples collected from different soil layers: $0-10 \mathrm{~cm}, 10-20 \mathrm{~cm}$ and $20-30 \mathrm{~cm}$. Soil samples were stored in an icebox for transport before being transferred into a freezer at $80{ }^{\circ} \mathrm{C}$. Samples were freeze-dried and sieved to remove the residues of animals and plants. The DNA extraction and Illumina MiSeq sequencing of the amplified DNA were carried out at Majorbio Bio Tech Co. Ltd (Shanghai, China). The database used for OTU identification were Silva and Unite (Kõljalg et al., 2013; Quast et al., 2013). We calculated the Shannon index to represent the diversity of bacteria and fungi, and analyzed the bacterial and fungal community compositions at the phylum level. At both sites, the relative abundance of microbial taxa less than $1 \%$ of total abundance were binned into 'unclassified' group.

\subsection{Statistical analysis}

Firstly, in order to compare the differences of litter traits and soil properties between sites, we carried out one-way analysis of variance (ANOVA) for each variable listed in Table 1. Secondly, we tested whether the mesh size, litter incubation treatments (Fig. 1), harvest time and their (full) interactions had significant effects on the litter losses of total 
mass, lignin, hemicellulose, cellulose and nutrients using three-way ANOVAs with Tukey's multiple comparisons. Thirdly, we divided the litter incubation treatments into litter origin and litter incubation and conducted additional four-way ANOVAs for the litter losses mentioned above (Table A1), and the relative contribution of either litter origin and litter incubation can be compared based on the F-values. Fourthly, we replaced the litter origin and litter incubation by each abiotic and biotic variable separately as listed in Table 1, and included each variable together with incubation time (the number of months, i.e. 5 and 9 months for the first and the second harvest respectively) in multiple regression analyses. We used the ' $\mathrm{lm}$ ' function in $\mathrm{R}$, in order to check the relative contribution of aboveground litter traits or belowground soil and microbial properties to the decomposition rates. In the end, for microbial community data, one-way ANOVA was also conducted to compare the difference in the diversity indices of bacteria and fungi, and the relative abundances of bacteria and fungi at the phylum level. Significant difference was detected at the level of $p<0.05$. All data were checked for homogeneity and normality before analysis and log-transformation was conducted when needed. Analyses were conducted either with SPSS 22.0 software (SPSS, Chicago, IL, USA) or with $R$ software 3.5.1 (R core Team, 2014).

\section{Results}

Initial $S$. salsa litter collected from site $\mathrm{S}$ (monospecific $S$. salsa) had significantly lower 
concentrations of total C, total P and lignin than that from site SP (mixture of S. salsa and P. australis, Table 1), but there were no significant differences in total $\mathrm{N}, \mathrm{C} / \mathrm{N}$, hemicellulose and cellulose contents of initial litter between the two sites (Table 1). For soil variables, site $\mathrm{S}$ had significantly higher soil concentrations of total $\mathrm{C}$, total $\mathrm{N}$, total $\mathrm{P}$, base cations than site $\mathrm{SP}$, and also had significantly higher $\mathrm{C} / \mathrm{N}$, organic matter content and electrical conductivity than site SP (Table 1). As to the soil microbes, there were ten phyla of bacteria and 12 phyla of fungi (excluding unclassified and small abundance groups) in both sites (Fig. 2). Moreover, site $\mathrm{S}$ had significantly lower soil fungal diversity than site SP, but there was no significant difference in soil bacteria diversity between the two sites (Table 1).

Litter incubation treatments (T1 to T4) had significant effects on the litter mass losses and on losses of total $\mathrm{C}$, total $\mathrm{N}$, total $\mathrm{P}$, lignin and hemicellulose (Table $2, p<0.01$, but for total $\mathrm{P}, p=0.05)$. Litter mass loss was the highest under T2, followed by $\mathrm{T} 1$ and $\mathrm{T} 3$; and the lowest mass loss was under T4 (Fig. 3a). The same pattern among treatments was found for litter lignin losses (Fig. 3c), but not for hemicellulose (Fig. 3e). Moreover, the highest $\mathrm{C}$ and $\mathrm{N}$ losses were observed under $\mathrm{T} 2$, followed by $\mathrm{T} 3$ and $\mathrm{T} 1$, and the lowest $\mathrm{C}$ and $\mathrm{N}$ losses were observed under T4 (Fig. 2b, 2d); but the highest P loss was observed under T3, followed by T2 and T4, while the lowest P loss was observed under T1 (Fig. 3e, 3f). In addition, harvest time had significant effects on litter decomposition (Table 1, 
Table A1, Fig. A1), but no significant effects of the mesh size (alone) were found on any of the decomposition variables mentioned above (Table 1).

By separating the incubation treatments into litter origin and litter incubation, we found that both litter origin and litter incubation had significant effects on the decomposition rates (Table A1, $p<0.05$ ), except for the effect of litter incubation on the total phosphorus losses $(p=0.26)$. Moreover, aboveground litter traits had larger explanatory power than belowground soil and microbial properties to the decomposition rates of $S$. salsa litter based on the adjusted $r^{2}$ of regression models (Table A2).

\section{Discussion}

Our reciprocal litter exchange experiment between monospecific $S$. salsa stands and mixed stands of $S$. salsa and P. australis yielded three key findings: (1) litter from the site without $P$. australis encroachment always decomposed faster than litter from the site with P. australis encroachment (Fig. 3, T1 > T4; T2 > T3), no matter where litter was incubated; (2) litter also decomposed faster when incubated at the site with P. australis encroachment than when incubated at the site without $P$. australis (Fig. 3, T2 > T1; T3 > T4), no matter where litter had been collected; (3) $\mathrm{C}$ and $\mathrm{P}$ losses, rather than $\mathrm{N}$ loss, was faster at the site with $P$. australis encroachment than that without $P$. australis (Fig. 3b, 3f; T3 > T1). The encroachment of such an ecosystem engineering species might affect the 
decomposition processes of salt marshes via both aboveground and belowground processes, as will be discussed in detail in the context of our results below. Indeed, the encroachment of $P$. australis might influence the allocation of total phosphorus between soil and plants (Table 1), leading to idiosyncratic P cycling in our study system compared to $\mathrm{C}$ and $\mathrm{N}$ cycling. Note that $S$. salsa litter mass loss had reached nearly $50 \%$ after the frozen season (Fig. A1). This is likely a consequence of both leaching of soluble organic compounds and microbial decomposition shortly before and after the frozen season.

4.1 Phragmites australis as an ecosystem engineer affected the decomposition rates of $S$. salsa litter via aboveground processes

When in mixture with $P$. australis, S. salsa tended to produce litter with higher concentrations of total $\mathrm{C}$, total $\mathrm{P}$ and lignin (Table 1). Litter decomposition rates have usually been found to be correlated with the initial chemical qualities in litter, such as total N, total P, C/N and lignin concentration (Cornwell et al., 2008; Hobbie, 2008). Our results confirmed that the $S$. salsa litter with lower initial lignin concentration had faster mass losses, and this was also shown by our multiple regression analyses, i.e. higher initial lignin concentrations led to lower decomposition rates (Table A2), except for the loss of total P. This might be due to faster release of total P from the $S$. salsa litter (Fig. A1), or due to the unique changes in phosphorus allocation between $S$. salsa litter and the soil, or due to the significantly higher concentrations of total P (nearly 1.5 fold) in the 
high lignin litter. In addition, our results did not show a positive correlation between litter decomposition rate and the initial total $\mathrm{P}$ in litters (Table 1: $691.97 \mu \mathrm{g} \mathrm{g}^{-1}$ for site $\mathrm{S}$ vs. 1069.13 $\mu \mathrm{g} \mathrm{g}^{-1}$ for site SP), which was inconsistent with other decomposition studies (Cornwell et al., 2008; Pan et al., 2014). The obvious interpretation might be that total P of $S$. salsa litter was not a strong limiting factor for $S$. salsa decomposition, which is consistent with the relatively high fraction of P loss in all treatments (Fig. 3). In contrast, litter lignin concentration did play a predominant role in determining the decomposition rates of $S$. salsa litter, especially for the whole-plant litter, in this coastal wetland ecosystem. Lignin in stems of $S$. salsa could protect labile litter components such as hemicellulose and protein from microbial attack (Berg and McClaugherty, 2008) and the release of labile compounds is often assumed to drive lignin breakdown by decomposers (Talbot and Treseder, 2012). This protection by lignin was indicated by our results: at the first harvest the loss of lignin was significantly faster than that of hemicellulose, but at the second harvest the differences between lignin loss and hemicellulose disappeared (Fig. A1).

4.2 Phragmites australis as an ecosystem engineer affected the decomposition rate of $S$. salsa litter via belowground processes

The presence of $P$. australis always led to faster decomposition rates of $S$. salsa litter. The best explanation for the faster decomposition rate in site SP might be that $P$. australis 
brings in both oxygen (being a helophyte with aerenchyma and perhaps through its rhizomes, Armstrong and Armstrong, 1988) and fresh water (thereby reducing salinity and associated electrical conductivity). Moreover, in coastal wetlands, salinity is found to be closely linked to soil organic content and decomposition (Morrissey et al., 2014), but low electrical conductivity, indicating low salinity, might have positive, neutral or negative effects on decomposition depending on the salinity level and the ecosystem concerned (Rejmánková and Houdková, 2006; Rejmánková and Sirová, 2007). Moreover, multiple soil properties might have mixed effects on the decomposition rates of $S$. salsa litter, and our data cannot clarify the relative contribution of each soil property to the decomposition rates regrettably. However, the effects of soil properties on litter decomposition rates were considered to be relatively indirect compared to soil decomposers, such as soil fungi, which could indicate the net indirect effects of soil properties on decomposition processes.

Soil decomposers are closely linked to decomposition rates and they are usually categorized into (fragmenting) soil invertebrates and soil microbes. We did not detect the effects of soil invertebrates on the decomposition rates of $S$. salsa litter in our study site by using litter bags with different mesh sizes (Table 2, no effects of mesh size on decomposition). However, we did find a higher diversity of fungal (but not bacteria) in the mixed community of $S$. salsa with $P$. australis than in the monospecific $S$. salsa 
community, and the factors that lead to this higher fungal diversity in the mixed community - for instance doubling of litter types, higher soil oxygenation or lower soil salinity - deserve in-depth study. Moreover, higher diversities of bacteria and fungi led to higher decomposition rates of $S$. salsa litter (Table A2). The above results indicate that fungi might play the vital role in determining the decomposition rates of $S$. salsa litter in this coastal wetland, especially for the nitrogen cycling of $S$. salsa litter. Based on the multiple regression analyses, we only found the diversity of microbial organisms have a significant power in explaining the total nitrogen losses of $S$. salsa litter, which was similar to the results found in other wetland ecosystems (Gulis and Suberkropp, 2003; Meier and Bowman, 2010). In addition, we only found the 'home-field advantage' evidence with the encroachment of $P$. australis (Fig. 3a), and the 'home-field advantage' for litter decomposition mainly operate via the belowground decomposers (Ayres et al., 2009; Luai et al., 2018). This might partly infer the significant role of $P$. australis as an engineer species in altering the $S$. salsa community belowground, notably the soil fungi diversity.

\section{Conclusion}

Our findings showed that $P$. australis as an ecosystem engineer might have significant consequences for the decomposition rates of $S$. salsa litter, via both aboveground and belowground pathways. Specifically, $P$. australis encroachment might affect the 
decomposition rate of $S$. salsa litter by making $S$. salsa produce litter with higher lignin concentrations, and leading to lower soil $\mathrm{N}$ and $\mathrm{P}$ availability but possibly higher oxygen availability and lower salinity as well as higher soil fungal diversity for decomposition.

Moreover, $P$. australis as an ecosystem engineer might also alter the allocation of total $\mathrm{P}$ between plants and soils in coastal wetlands, and in turn affect the aboveground and belowground mechanisms in controlling decomposition. These results together indicated that the encroachment of $P$. australis, no matter what drives this encroachment, could lead to substantial changes in both abiotic and biotic factors, and adds to the increasing evidence that plant community shifts might be more important than the abiotic factors in controlling decomposition (Cornelissen et al., 2007; Hooper et al., 2012), especially when the shifts are caused by ecosystem engineers. Our findings also highlight the important consequences of plant encroachments in determining the carbon and nutrient cycles in coastal wetlands, as well as in evaluating the ecosystem functions and services of coastal wetlands more generally.

\section{Acknowledgements}

This work was funded by National Key R\&D Program of China (2017YFC0506200), and China Postdoctoral Science Foundation (2015M571161). J.H.C.C. received support from the Royal Netherlands Academy of Arts and Sciences (KNAW, Chinese Exchange Programme grant 12CDP007) for research exchange travels to China. We thank the 
Liaohe Estuary National Nature Reserve for the research permit and thank Jing Li and Xiufang Xie for the manuscript preparation. Many thanks to Ye Liu, Baodi Sun, Kai Li and Xiaoquan $\mathrm{Na}$ for the field assistant. We also thank the anonymous referees for constructive comments on an earlier version of this manuscript. The authors have no conflicts of interest to declare. 


\section{References}

Archer, S.R., Andersen, E.M., Predick, K.I., Schwinning, S., Steidl, R.J., Woods, S.R., 2017. Woody plant encroachment: causes and consequences. In: Briske, D. (Eds) Rangeland Systems. Springer, Cham, pp. 25-84.

Armstrong, J., Armstrong, W., 1988. Phragmites australis - A preliminary study of soiloxidizing sites and internal gas transport pathways. New Phytol. 108, 373-382. https://doi.org/10.1111/j.1469-8137.1988.tb04177.x

Ayres E., Steltzer H., Simmons B.L., Simpson R.T., Steinweg J.M., Wallenstein M.D., Mellor N., Parton W.J., Moore J.C., Wall D.H., 2009. Home-field advantage accelerates leaf litter decomposition in forests. Soil Biol. Biochem. 41: 606-610. https://doi.org/10.1016/j.soilbio.2008.12.022

Belnap, J., Phillips, S.L., Sherrod, S.K., Moldenke, A., 2005. Soil biota can change after exotic plant invasion: does this affect ecosystem processes? Ecology 86, 3007-3017. https://doi.org/10.1890/05-0333

Berendse, F., Van Breemen, N., Rydin, H., Buttler, A., Heijmans, M., Hoosbeek, M.R., Lee, J.A., Mitchell, E., Saarinen, T., Vasander, H., 2001. Raised atmospheric $\mathrm{CO}_{2}$ levels and increased $\mathrm{N}$ deposition cause shifts in plant species composition and production in Sphagnum bogs. Global Change Biol. 7, 591-598. https://doi.org/10.1046/j.1365-2486.2001.00433.x

Berg, B., McClaugherty, C., 2008. Plant Litter: Decomposition, Humus Formation, 
Carbon Sequestration. Springer, Berlin, Heidelberg.

Bernal, B., Megonigal, J.P., Mozdzer, T.J., 2017. An invasive wetland grass primes deep soil carbon pools. Global Change Biol. 23, 2104-2116.

https://doi.org/10.1111/gcb.13539

Cornelissen, J.H.C., van Bodegom, P.M., Aerts, R., Callaghan, T.V., van Logtestijn, R.S.P., Alatalo, J., Chapin, F.S., Gerdol, R., Gudmundsson, J., Gwynn-Jones, D., Hartley, A.E., Hik, D.S., Hofgaard, A., Jónsdóttir, I.S., Karlsson, S., Klein, J.A., Laundre, J., Magnusson, B., Michelsen, A., Molau, U., Onipchenko, V.G., Quested, H.M., Sandvik, S.M., Schmidt, I.K., Shaver, G.R., Solheim, B., Soudzilovskaia, N.A., Stenstrom, A., Tolvanen, A., Totland, Ø., Wada, N., Welker, J.M., Zhao, X.Q., Team, M.O.L., 2007. Global negative vegetation feedback to climate warming responses of leaf litter decomposition rates in cold biomes. Ecol. Lett. 10, 619-627. https://doi.org/10.1111/j.1461-0248.2007.01051.x

Cornwell, W.K., Cornelissen, J.H.C., Amatangelo, K., Dorrepaal, E., Eviner, V.T., Godoy, O., Hobbie, S.E., Hoorens, B., Kurokawa, H., Pérez-Harguindeguy, N., Quested, H.M., Santiago, L.S., Wardle, D.A., Wright, I.J., Aerts, R., Allison, S.D., van Bodegom, P., Brovkin, V., Chatain, A., Callaghan, T.V., Díaz, S., Garnier, E., Gurvich, D.E., Kazakou, E., Klein, J.A., Read, J., Reich, P.B., Soudzilovskaia, N.A., Vaieretti, M.V., Westoby, M., 2008. Plant species traits are the predominant control on litter decomposition rates within biomes worldwide. Ecol. Lett. 11, 1065-1071. 
https://doi.org/10.1111/j.1461-0248.2008.01219.x

Díaz, S., Lavorel, S., de Bello, F., Quétier, F., Grigulis, K., Robson, T.M., 2007.

Incorporating plant functional diversity effects in ecosystem service assessments.

Proc. Nat. Acad. Sci. 104, 20684-20689. https://doi.org/10.1073/pnas.0704716104

Ehrenfeld, J.G., Parsons, W.F.J., Han, X., Parmelee, R.W., Zhu, W., 1997. Live and dead roots in forest soil horizons: contrasting effects on nitrogen dynamics. Ecology 78, 348-362. https://doi.org/10.1890/0012-9658(1997)078[0348:LADRIF]2.0.CO;2

Eldridge, D. J., Bowker, M. A., Maestre, F. T., Roger, E., Reynolds, J. F., Whitford, W. G., 2011. Impacts of shrub encroachment on ecosystem structure and functioning: towards a global synthesis. Ecol. Lett. 14: 709-722. https://doi.org/10.1111/j.1461$\underline{0248.2011 .01630 . x}$

FAO, 2006. World reference base for soil resources 2006. http://www.fao.org/3/aa0510e.pdf

Freschet, G.T., Cornelissen, J.H.C., Van Logtestijn, R.S.P., Aerts, R., 2010. Evidence of the 'plant economics spectrum' in a subarctic flora. J. Ecol. 98, 362-373. https://doi.org/10.1111/j.1365-2745.2009.01615.x

Friedrich, U., von Oheimb, G., Dziedek, C., Kriebitzsch, W-U., Selbmann, K., Härdtle, W., 2011. Mechanisms of purple moor-grass (Molinia caerulea) encroachment in dry heathland ecosystems with chronic nitrogen inputs. Environ. Poll. 159, 35533559. https://doi.org/10.1016/j.envpol.2011.08.010 
Gedan, K.B., Bertness, M.D., 2009. Experimental warming causes rapid loss of plant diversity in New England salt marshes. Ecol. Lett. 12, 842-848. https://doi.org/10.1111/j.1461-0248.2009.01337.x

Graça, M.A.S., 2001. The role of invertebrates on leaf litter decomposition in streams - a review. Int. Rev. Hydrobiol. 86, 383-393. https://doi.org/10.1002/15222632(200107)86:4/5<383::AID-IROH383>3.0.CO;2-D

Gulis, V., Suberkropp, K., 2003. Effect of inorganic nutrients on relative contributions of fungi and bacteria to carbon flow from submerged decomposing leaf litter. Microb. Ecol. 45, 11-19. https://doi.org/10.1007/s00248-002-1032-1

Guy-Haim, T., Lyons, D.A., Kotta, J., Ojaveer, H., Queirós, A.M., Chatzinikolaou, E., Arvanitidis, C., Como, S., Magni, P., Blight, A.J., Orav-Kotta, H., Somerfield, P.J., Crowe, T.P., Rilov, G., 2018. Diverse effects of invasive ecosystem engineers on marine biodiversity and ecosystem functions - a global review and meta-analysis. Global Change Biol.24, 906-924. https://doi.org/10.1111/gcb.14007

Hibbard, K.A., Archer, S., Schimel, D. S., \& Valentine, D. W., 2001. Biogeochemical changes accompanying woody plant encroachment in a subtropical savanna.

Ecology 82, 1999-2011. https://doi.org/10.1890/00129658(2001)082[1999:BCAWPE]2.0.CO;2

Hobbie, S.E., 2008. Nitrogen effects on decomposition: a five-year experiment in eight temperate sites. Ecology 89, 2633-2644. https://doi.org/10.1890/07-1119.1 
Hooper, D.U., Adair, E.C., Cardinale, B.J., Byrnes, J.E., Hungate, B.A., Matulich, K.L., Gonzalez, A., Duffy, J.E., Gamfeldt, L., O’Connor, M.I., 2012. A global synthesis reveals biodiversity loss as a major driver of ecosystem change. Nature 486, $105-$ 108. https://doi.org/10.1038/nature11118

Hughes, A.R., Schenck, F.R., Bloomberg, J., Hanley, T.C., Feng, D., Gouhier, T.C., Beighley, R.E., Kimbro, D.L., 2016. Biogeographic gradients in ecosystem processes of the invasive ecosystem engineer Phragmites australis. Biol. Invasions 18, 2577-2595. https://doi.org/10.1007/s10530-016-1143-0

Kelleway, J.J., Cavanaugh, K., Rogers, K., Feller, I.C., Ens, E., Doughty, C., Saintilan, N., 2017. Review of the ecosystem service implications of mangrove encroachment into salt marshes. Global Change Biol. 23, 3967-3983.

https://doi.org/10.1111/gcb.13727

Kõljalg, U., Nilsson, R.H., Abarenkov, K., Tedersoo, L., Taylor, A.F., Bahram, M., Bates, S.T., Bruns, T.D., Bengtsson-Palme, J., Callaghan, T.M., 2013. Towards a unified paradigm for sequence-based identification of fungi. Mol. Ecol. 22, 5271-5277. https://doi.org/10.1111/mec.12481

Luai, V.B., Ding, S., Wang, D., 2019. The effects of litter quality and living plants on the home-field advantage of aquatic macrophyte decomposition in a eutrophic urban lake, China. Sci. Total Environ. 650, 1529-1536. https://doi.org/10.1016/j.scitotenv.2018.09.104 
McLaren, J.R., Buckeridge, K.M., van de Weg, M.J., Shaver, G.R., Schimel, J.P., Gough, L., 2017. Shrub encroachment in Arctic tundra: Betula nana effects on above- and below-ground litter decomposition. Ecology 98, 1361-1376.

https://doi.org/10.1002/ecy.1790

McLusky, D.S., Elliott, M., 2004. The Estuarine Ecosystem: Ecology, Threats and Management. Oxford University Press, Oxford.

Meier, C.L., Bowman, W.D., 2010. Chemical composition and diversity influence nonadditive effects of litter mixtures on soil carbon and nitrogen cycling: implications for plant species loss. Soil Biol. Biochem. 42, 1447-1454.

https://doi.org/10.1016/j.soilbio.2010.05.005

Minchinton, T.E., Bertness, M.D., 2003. Disturbance- mediated competition and the spread of Phragmites australis in a coastal marsh. Ecol. Appl. 13, 1400-1416. https://doi.org/10.1890/02-5136

Morrissey, E.M., Gillespie, J.L., Morina, J.C., Franklin, R.B., 2014. Salinity affects microbial activity and soil organic matter content in tidal wetlands. Global Change Biol. 20, 1351-1362. https://doi.org/10.1111/gcb.12431

Nolte, S., Wanner, A., Stock, M., Jensen, K., 2019. Elymus athericus encroachment in Wadden Sea salt marshes is driven by surface elevation change. Appl. Veg. Sci. https://doi.org/10.1111/avsc. 12443

Otto, S., Groffman, P.M., Findlay, S.E., Arreola, A.E., 1999. Invasive plant species and 
microbial processes in a tidal freshwater marsh. J. Environ. Qual. 28, 1252-1257. https://doi.org/10.2134/jeq1999.00472425002800040028x

Pan, X., Cornelissen, J.H.C., Zhao, W.W., Liu, G.F., Hu, Y.K., Prinzing, A., Dong, M., Cornwell, W.K., 2014. Experimental evidence that the Ornstein-Uhlenbeck model best describes the evolution of leaf litter decomposability. Ecol. Evol. 4, 3339-3349. https://doi.org/10.1002/ece3.1115

Pan, X., Song, Y.B., Jiang, C., Liu, G.F., Ye, X.H., Xie, X.F., Hu, Y.K., Zhao, W.W., Cui, L.J., Cornelissen, J.H.C., 2015. Evolutionary position and leaf toughness control chemical transformation of litter, and drought reinforces this control: evidence from a common garden experiment across 48 species. PLoS ONE 10, e0143140. https://doi.org/10.1371/journal.pone.0143140

Powell, K.I., Chase, J.M., Knight, T.M., 2011. A synthesis of plant invasion effects on biodiversity across spatial scales. Am. J. Bot. 98, 539-548. https://doi.org/10.3732/ajb.1000402

Quast, C., Pruesse, E., Yilmaz, P., Gerken, J., Schweer, T., Yarza, P., Peplies, J., Glöckner, F.O., 2013. The SILVA ribosomal RNA gene database project: improved data processing and web-based tools. Nucl. Acids Res. 41, D590-D596. https://doi.org/10.1093/nar/gks1219

Quintino, V., Sangiorgio, F., Ricardo, F., Mamede, R., Pires, A., Freitas, R., Rodrigues, A.M., Basset, A., 2009. In situ experimental study of reed leaf decomposition along 
a full salinity gradient. Estuar. Coast. Shelf Sci. 85, 497-506.

https://doi.org/10.1016/j.ecss.2009.09.016

R Core Team, 2014. R: A Language and Environment for Statistical Computing. Vienna:

R Foundation for Statistical Computing.

Ravit, B., Ehrenfeld, J.G., Haggblom, M.M., 2003. A comparison of sediment microbial communities associated with Phragmites australis and Spartina alterniflora in two brackish wetlands of New Jersey. Estuaries 26, 465-474.

https://doi.org/10.1007/BF02823723

Rejmánková, E., Houdková, K., 2006. Wetland plant decomposition under different nutrient conditions: what is more important, litter quality or site quality?

Biogeochemistry 80, 245-262. https://doi.org/10.1007/s10533-006-9021-y

Rejmánková, E., Sirová, D., 2007. Wetland macrophyte decomposition under different nutrient conditions: relationships between decomposition rate, enzyme activities and microbial biomass. Soil Biol. Biochem. 39, 526-538.

https://doi.org/10.1016/j.soilbio.2006.08.022

Rooth, J.E., Stevenson, J.C., 2000. Sediment deposition patterns in Phragmites australis communities: implications for coastal areas threatened by rising sea-level. Wetlands Ecol. Manage. 8, 173-183. https://doi.org/10.1023/A:1008444502859

Schlesinger, W.H., Reynolds, J.F., Cunningham, G.L., Huenneke, L.F., Jarrell, W.M., Virginia, R.A., Whitford, W.G., 1990. Biological feedbacks in global desertification. 
Science 247, 1043-1048. https://doi.org/10.1126/science.247.4946.1043

Song, J., Shi, G., Gao, B., Fan, H., Wang, B., 2011. Waterlogging and salinity effects on two Suaeda salsa populations. Physiol. Plant. 141, 343-351. https://doi.org/10.1111/j.1399-3054.2011.01445.x

Talbot, J.M., Treseder, K.K., 2012. Interactions among lignin, cellulose, and nitrogen drive litter chemistry-decay relationships. Ecology 93, 345-354. https://doi.org/10.1890/11-0843.1

Templer, P., Findlay, S., Wigand, C., 1998. Sediment chemistry associated with native and non-native emergent macrophytes of a Hudson River marsh ecosystem.

Wetlands 18, 70-78. https://doi.org/10.1007/BF03161444

Vitousek, P.M., 1990. Biological invasions and ecosystem processes: towards an integration of population biology and ecosystem studies. Oikos 57, 7-13. https://doi.org/10.2307/3565731

Wardle, D.A., Bardgett, R.D., Klironomos, J.N., Setälä, H., van der Putten, W.H., Wall, D.H., 2004. Ecological linkages between aboveground and belowground biota. Science 304, 1629-1633. https://doi.org/10.1126/science.1094875

Warren, R.S., Fell, P.E., Grimsby, J.L., Buck, E.L., Rilling, G.C., Fertik, R.A., 2001. Rates, patterns, and impacts of Phragmites australis expansion and effects of experimental Phragmites control on vegetation, macroinvertebrates, and fish within tidelands of the lower Connecticut River. Estuaries 24, 90-107. 
https://doi.org/10.2307/1352816

Windham, L., Ehrenfeld, J.G., 2003. Net impact of a plant invasion on nitrogen-cycling processes within a brackish tidal marsh. Ecol. Appl. 13, 883-896. https://doi.org/10.1890/02-5005

Wu, T., Zhao, D., Kang, J., Zhang, F., Cheng, L., 2011. Suaeda salsa dynamic remote monitoring and biomass remote sensing inversion in Shuangtaizi River estuary. Ecol. Environ. 20, 24-29. https://doi.org/10.11834/jrs.20166168

Zhao, K., Fan, H., Jiang, X., Zhou, S., 2002. Critical day-length and photoinductive cycles for the induction of flowering in halophyte Suaeda salsa. Plant Science 162, 27-31. https://doi.org/10.1016/S0168-9452(01)00520-9

Zhou, Y., Boutton, T.W., Wu, X.B., 2018. Soil C:N:P stoichiometry responds to vegetation change from grassland to woodland. Biogeochemistry 140, 341-357. https://doi.org/10.1007/s10533-018-0495-1 


\section{Figure captions}

Fig. 1 The design of the litter transplantation experiment. Treatment 1 (T1) represents $S$. salsa litter from site $\mathrm{S}$ (which only hosts $S$. salsa stands) incubated at site S; Treatment 2 (T2) represents $S$. salsa litter from site S incubated at site SP (which hosts $S$. salsa coexisting with $P$. australis); Treatment 3 (T3) represents $S$. salsa litter from site SP incubated at site SP; Treatment 4 (T4) represents $S$. salsa litter from site SP incubated at site $\mathrm{S}$.

Fig. 2 Relative abundances of soil (a) bacterial and (b) fungal community composition at phylum level between site S (which only hosts $S$. salsa stands) and site SP (which hosts S. salsa coexisting with $P$. australis). Sequences that could not be classified into any known group were sorted as "others", so were the groups whose relative abundance was smaller than $1 \%$ at both sites. Error bars represent standard errors $(n=3)$.

Fig. 3 Effects of litter incubation treatments on litter mass loss, lignin loss, hemicellulose loss and litter nutrient losses (total $\mathrm{C}$, total $\mathrm{N}$ and total P losses). Treatment 1 (T1) represents $S$. salsa litter from site $\mathrm{S}$ incubated at site S; Treatment 2 (T2) S. salsa litter from site S incubated at site SP; Treatment 3 (T3) S. salsa litter from site $S$ incubated at site SP; Treatment 4 (T4) S. salsa litter from site SP incubated at site S. a-d represent the multiple comparison results among different litter incubation treatments. Significance is shown at the level of $p<0.05$. Bars show standard errors $(n=5)$. 


\section{CRediT author statement}

Lijuan Cui: Conceptualization, Supervision. Xu Pan: Methodology, Formal Analysis, Writing - Original Draft. Wei Li: Resources, Investigation. Xiaodong Zhang: Data Curation. Guofang Liu: Software, Writing - Review \& Editing. Yao-Bin Song: Validation. Fei-Hai Yu: Data Curation, Writing - Review \& Editing. Andreas Prinzing: Supervision, Writing - Review \& Editing. Johannes H. C. Cornelissen: Conceptualization, Methodology, Supervision, Writing - Review \& Editing. 
Table 1 Summary and comparison of litter traits and soil properties between two sites with and without $P$. australis encroachment. Significant differences between sites are shown in bold at the level of $p<0.05$.

\begin{tabular}{|c|c|c|}
\hline Litter traits and soil properties & $\begin{array}{c}\text { Site } \mathrm{S} \\
\text { (without } \\
\text { P. australis) }\end{array}$ & $\begin{array}{c}\text { Site SP } \\
\text { (with } \\
\text { P. australis) }\end{array}$ \\
\hline \multicolumn{3}{|l|}{ Litter } \\
\hline $\mathrm{C}(\%)$ & $24.73 \pm 1.51$ & $29.12 \pm 2.69$ \\
\hline $\mathrm{N}(\%)$ & $0.60 \pm 0.04$ & $0.70 \pm 0.15$ \\
\hline $\mathrm{C} / \mathrm{N}$ & $41.20 \pm 4.45$ & $43.34 \pm 11.87$ \\
\hline $\mathrm{P}\left(\mu \mathrm{g} \mathrm{g}^{-1}\right)$ & $691.97 \pm 74.60$ & $1069.13 \pm 184.83$ \\
\hline Hemicellulose $(\%)$ & $5.62 \pm 0.72$ & $5.43 \pm 0.10$ \\
\hline Cellulose $(\%)$ & $19.64 \pm 0.32$ & $18.75 \pm 2.31$ \\
\hline Lignin $(\%)$ & $22.39 \pm 1.05$ & $26.17 \pm 1.75$ \\
\hline \multicolumn{3}{|l|}{ Soil } \\
\hline $\mathrm{C}(\%)$ & $1.020 \pm 0.12$ & $0.575 \pm 0.04$ \\
\hline $\mathrm{N}(\%)$ & $0.08 \pm 0.01$ & $0.05 \pm 0.01$ \\
\hline $\mathrm{C} / \mathrm{N}$ & $12.533 \pm 0.205$ & $11.605 \pm 0.343$ \\
\hline $\mathrm{P}\left(\mathrm{mg} \mathrm{g}^{-1}\right)$ & $757.81 \pm 74.08$ & $482.62 \pm 97.16$ \\
\hline Base cations $\left(\mathrm{mg} \mathrm{g}^{-1}\right)$ & $49.00 \pm 3.90$ & $36.385 \pm 0.74$ \\
\hline Organic matter $\left(\mathrm{mg} \mathrm{g}^{-1}\right)$ & $10.72 \pm 0.80$ & $8.01 \pm 0.75$ \\
\hline Electrical conductivity ( $\mu \mathrm{s} \mathrm{cm}^{-1}$ ) & $4544 \pm 1048$ & $2385 \pm 490$ \\
\hline Microbe & & \\
\hline Shannon index of bacteria & $5.88 \pm 0.39$ & $6.54 \pm 0.04$ \\
\hline Shannon index of fungal & $3.09 \pm 0.08$ & $4.09 \pm 0.03$ \\
\hline
\end{tabular}


Table 2 ANOVAs of mesh size (M, coarse mesh or fine mesh), litter incubation treatment (T: T1, T2, T3, T4), harvest time (H: two harvests) on litter mass losses, lignin and hemicellulose losses and litter nutrient losses (total carbon, total nitrogen and total phosphorus losses). The degree of freedom for the errors equals 54 throughout.

Significant results at $p<0.05$ are shown in bold. Treatment 1 (T1) represents $S$. salsa litter from site $\mathrm{S}$ (which only hosts $S$. salsa stands) incubated at site $\mathrm{S}$; Treatment 2 (T2) represents $S$. salsa litter from site $S$ incubated at site SP (which hosts $S$. salsa coexisting with $P$. australis); Treatment 3 (T3) represents $S$. salsa litter from site SP incubated at site SP; Treatment 4 (T4) represents $S$. salsa litter from site SP incubated at site S.

\begin{tabular}{|c|c|c|c|c|c|c|c|c|c|c|c|c|c|}
\hline \multirow{2}{*}{$\begin{array}{c}\text { Variable } \\
\text { s }\end{array}$} & \multirow{2}{*}{$\begin{array}{l}d \\
f\end{array}$} & \multicolumn{2}{|c|}{$\begin{array}{l}\text { Mass } \\
\text { loss }\end{array}$} & \multicolumn{2}{|c|}{$\begin{array}{c}\text { Carbon } \\
\text { loss }\end{array}$} & \multicolumn{2}{|c|}{$\begin{array}{c}\text { Nitrogen } \\
\text { loss }\end{array}$} & \multicolumn{2}{|c|}{$\begin{array}{c}\text { Phosphoru } \\
\text { s loss }\end{array}$} & \multicolumn{2}{|c|}{$\begin{array}{l}\text { Lignin } \\
\text { loss }\end{array}$} & \multicolumn{2}{|c|}{$\begin{array}{l}\text { Hemicellulo } \\
\text { se loss }\end{array}$} \\
\hline & & $F$ & $p$ & & & $F$ & $p$ & $F$ & $p$ & $F$ & $p$ & $F$ & $p$ \\
\hline & & & & & & & $<$ & & $<$ & & $<$ & & \\
\hline Harvest & & 42. & 0.0 & 59. & 0.0 & 37. & 0.0 & 11.8 & 0.0 & 11. & 0.0 & 17.7 & $<$ \\
\hline (H) & 1 & 99 & & 26 & 1 & 65 & 1 & 0 & 1 & 62 & 1 & 0 & 0.01 \\
\hline Mesh & & 0.1 & 0.6 & 1.6 & 0.2 & 0.3 & 0.5 & & 0.2 & 0.0 & 0.9 & & \\
\hline size $(\mathrm{M})$ & 1 & 7 & 9 & 2 & 1 & 5 & 6 & 1.36 & 5 & 0 & 6 & 2.25 & 0.14 \\
\hline & & & $<$ & & $<$ & & $<$ & & & & $<$ & & \\
\hline Treatme & & 23. & 0.0 & 16. & 0.0 & 5.5 & 0.0 & & 0.0 & 17. & 0.0 & & $<$ \\
\hline nt $(\mathrm{T})$ & 3 & 23 & 1 & 06 & 1 & 8 & 1 & 2.76 & 5 & 69 & 1 & 5.54 & 0.01 \\
\hline & & 0.4 & 0.5 & 3.3 & 0.0 & 5.9 & 0.0 & & 0.2 & 0.0 & 0.7 & & \\
\hline $\mathrm{H} * \mathrm{M}$ & 1 & 4 & 1 & 2 & 7 & 8 & 2 & 1.53 & 2 & 8 & 9 & 1.49 & 0.23 \\
\hline
\end{tabular}




\begin{tabular}{cccccccccccccc}
\hline & & & \multicolumn{1}{c}{$<$} & & & & & & & & \\
$\mathrm{H} * \mathrm{~T}$ & 3 & $\mathbf{1}$ & $\mathbf{3}$ & $\mathbf{9}$ & $\mathbf{1}$ & $\mathbf{0}$ & $\mathbf{1}$ & 1.68 & 8 & 7 & 9 & $\mathbf{2 . 9 5}$ & $\mathbf{0 . 0 4}$ \\
& & 2.6 & 0.0 & 1.3 & 0.2 & 0.3 & 0.7 & & 0.2 & 3.9 & 0.0 & & \\
$\mathrm{M} * \mathrm{~T}$ & 3 & 5 & 6 & 3 & 8 & 8 & 7 & 1.48 & 3 & 9 & 1 & 1.25 & 0.30 \\
$\mathrm{H} * \mathrm{M} *$ & & 0.2 & 0.7 & 3.5 & 0.0 & 1.7 & 0.1 & & 0.7 & 0.3 & 0.6 & & \\
$\mathrm{~T}$ & 2 & 6 & 7 & 4 & 4 & 8 & 8 & 0.24 & 9 & 7 & 9 & 0.83 & 0.44 \\
\hline
\end{tabular}


Suaeda salsa

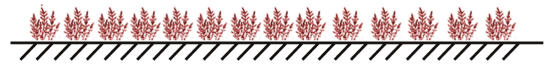

Suaeda salsa + Phragmites australis

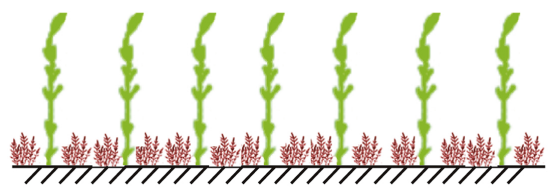

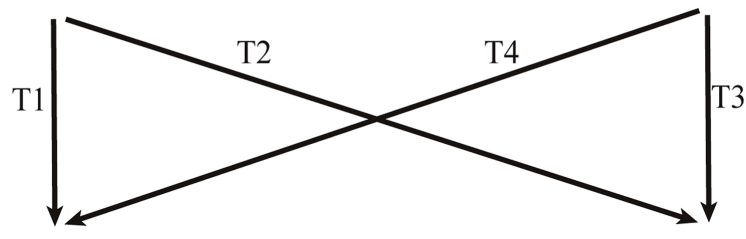
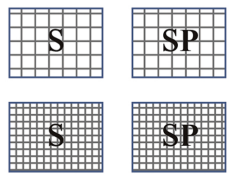
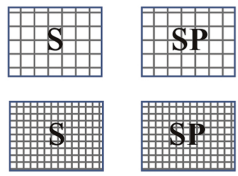

Figure 1 
(a) Bacteria

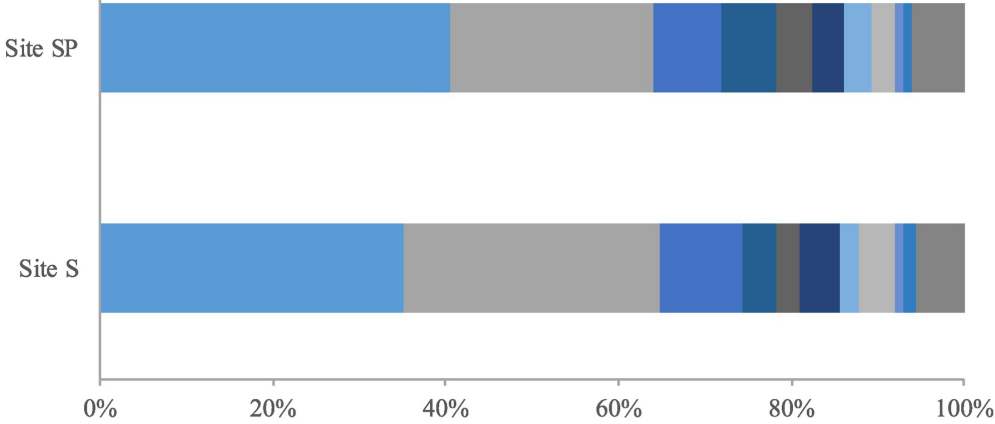

- Proteobacteria

- Bacteroidetes

nChloroflexi

- Planctomycetes

-Acidobacteria

-Gemmatimonadetes

Actinobacteria

- Cyanobacteria

- Lentisphaerae

- Latescibacteria

च Others

(b) Fungi

Site SP
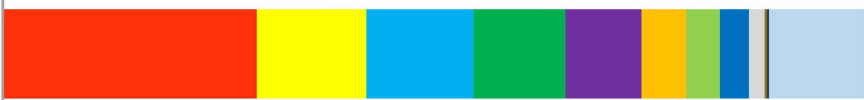

Site S

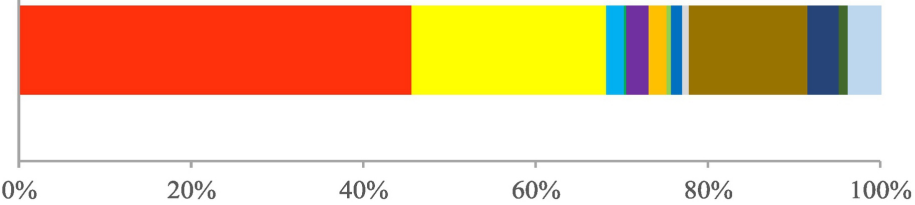

- Ascomycota

Basidiomycota

- Eukaryota

Nematoda

- Chytridiomycota

n Ciliophora

- Corallochytrea

- Choanomonada

- Freshwater_Opisthokonta

- Ochrophyta

- Cryptomonadales

- Phragmoplastophyta

Others

Relative abundance of soil bacteria and fungi(\%)

Figure 2 

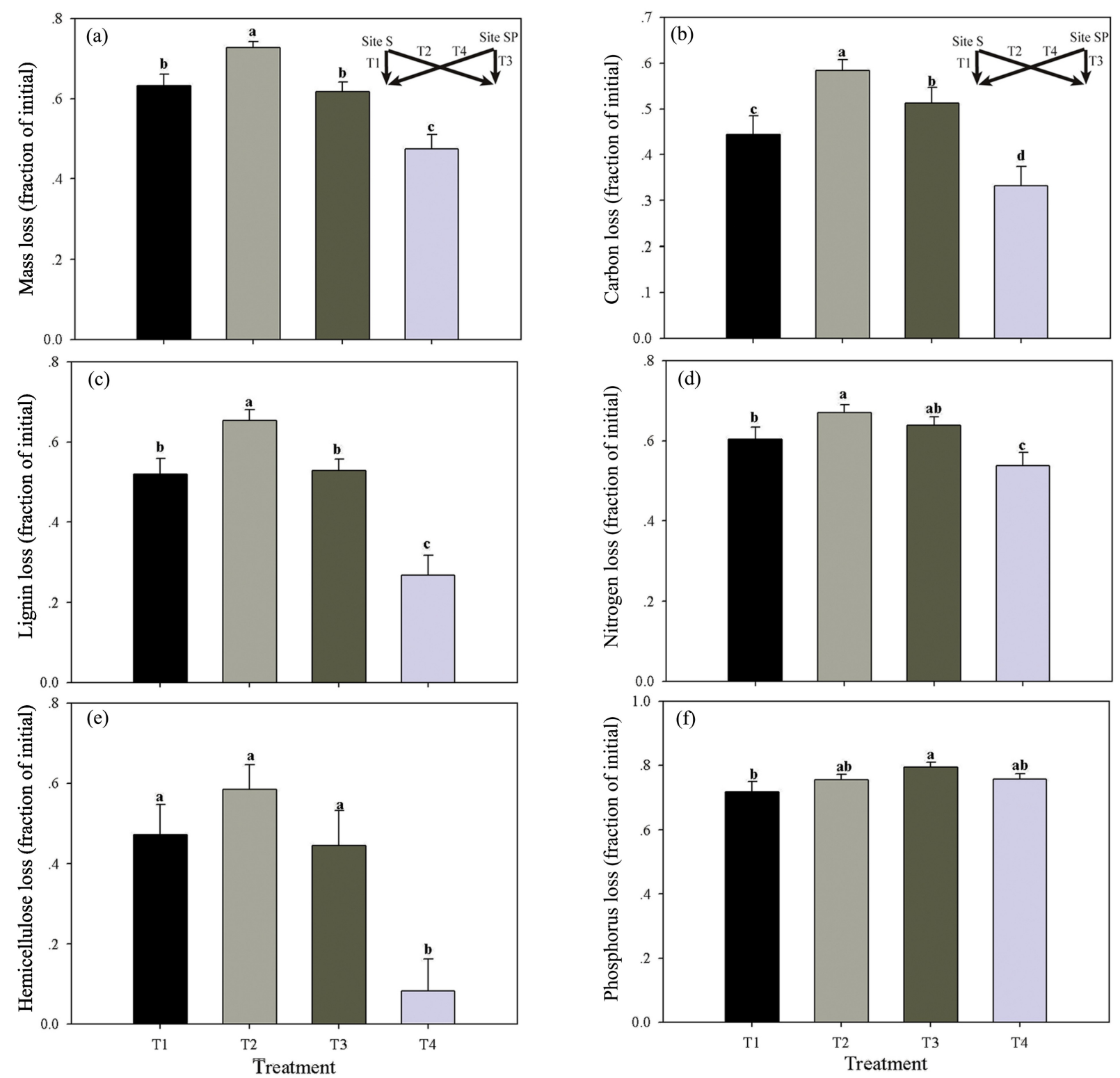

Figure 3 